\title{
Healing Effects of Formulations with Extract of Sonchus oleraceus
}

\author{
Idelvânia dos Anjos Nonato', Marlene Isabel Vargas Viloria², Gabriel Domingos Carvalho³, Fabrício Luciani \\ Valente' ${ }^{2}$, Joaquín Hernán Patarroyo Salcedo², Marcelo Barcellos Da Rosa ${ }^{4}$ \& Camilo Amaro de Carvalho ${ }^{5}$
}

\begin{abstract}
Introduction: Scar is defined as a process of tissue regeneration characterized by fibroblasts and a disorganized extracellular matrix, formed mainly by collagen. Thus it is understood that regeneration capacity is a phenomenon that occurs in order to repair an injured tissue. However, science has been looking for alternatives to assist in the repair process, and thus phytotherapy has been used as a therapeutic resource in medicine, and scientifically proven its efficiency. The plant Sonchus oleraceus is known, among other names, as "serralha" or sowthistle. It is a cosmopolitan species, found in several agricultural regions infesting crops. In Brazil, it is more frequent to grow in the winter and its seeds can be kept viable for eight years in the soil. This plant can be used as a popular drug for diuretic proposals, in cases of anemia, liver diseases and in cases of treatment of vitiligo in the eastern region of the state of Minas Gerais, Brazil. The objective of this research was to evaluate two different products (ointment and balsam) composed by S. oleraceus in the healing of surgical wounds in rats (Rattus novergicus).

Materials, Methods \& Results: Sonchus oleraceus specimens were obtained at the beginning of May, during the autumnwinter season, in which there is already a flowering of this plant. The leaves and stem of S. oleraceus were selected, cleaned and dried under study at $40^{\circ} \mathrm{C}$ of circulating air for four days for complete dehydration, and then ground in a knife mill. The constituents were prepared in $80 \%$ alcohol (v/v) and subjected to ultrasonic extraction for $60 \mathrm{~min}$. The hydroalcoholic extract of S. oleraceus was concentrated on a rotary evaporator until all alcohol evaporated and the aqueous extract was obtained. The extracts were produced at concentrations of 5\%,10\% and $15 \%$ and sent for manipulation of the pharmaceutical formulations of ointment and salve. Forty Wistar rats were divided into eight groups for evaluation of different products (salve and ointment). The wounds were created on the back of the animals and the products were applied daily; for analysis, clinical evaluations and wound measurement were performed daily. After 15 days, a biopsy was performed for histopathological analysis and quantification of type I and III collagen fibers. Measurement of the wound in rats treated with ointment containing $15 \%$ of extract presented better tissue retraction, with complete retraction observed after 10 days of treatment. Type I collagen was predominant in all samples; however, the healing properties of the balsam containing $5 \%$ extract and ointment containing 5\% and $15 \%$ extract were significantly different.

Discussion: As a conclusion, Sonchus oleraceus influenced the healing process of the skin. This pharmacological action is probably directly related to the amount of flavonoids present in its composition, that is, the higher the extract concentration, the better its efficacy. However, a better efficacy in the ointment is emphasized by better adhesion to the skin. Studies have shown that the flavonoids present in most plants have relevant healing activity, stimulating the proliferation of fibroblasts and the production of collagen, acting on the inhibition of metalloproteinase, thus increasing the rate of synthesized collagen. Other researchers reported a high concentration of flavonoids (anthocyanins and tannins) that act as mediators of inflammation, stimulating the production of inflammatory cytokines and tumor necrosis factor, observed in this species.
\end{abstract}

Keywords: healing, collagen, sow thistle, tissue regeneration. 


\section{INTRODUCTION}

The treatment of wounds has been researched for a long time and many researchers have proposed improvements to the applied interventions [17]. The use of medicinal plants in Brazil has origins in Indigenous and African cultures and the chemical and biological functions of the responsible active principles is a topic of great interest for researchers of medicinal plants. According the World Health Organization, $85 \%$ of the population of developing countries makes use of medicinal plants in their natural form or as herbal remedies [5]. The Brazil National Agency of Sanitary Surveillance (ANVISA) defines phytotherapeutic medicines as a medication originating from plants, without the addition of isolated drugs that may damage human health [12].

The plant $S$. oleraceus is known, among other names, as "serralha" or sowthistle. It is a cosmopolitan species and an agricultural plague in crops. In Brazil, it grows more frequently in winter and the seeds may remain viable in the ground for up to 8 years. The plant is a popular medicine, useful as a diuretic and for the treatment of anemia, liver diseases, and vitiligo in the eastern region of the state of Minas Gerais, Brazil [10,14].

The objective of this study was to evaluate the healing properties of two products (an ointment and a balm) made from the extract of Sonchus oleraceus on surgically induced wounds.

\section{MATERIALS AND METHODS}

\section{Extract preparation}

The leaves and plant stems of Sonchus oleraceus specimens were selected, cleaned, completely dried in oven at $40^{\circ} \mathrm{C}$ with circulating air, and pulverized. Following the method of Carvalho [6], the resulting material was mixed with alcohol $80 \%(\mathrm{v} / \mathrm{v})$ and subjected to ultrasound (Unique ${ }^{\circledR}$ - MaxiClean 1400) ${ }^{1}$ extraction for $60 \mathrm{~min}$. The mixture was subsequently filtered under vacuum to obtain the maximum volume of solution separated from the dry matter.

The hydroalcoholic extract of S. oleraceus was concentrated in a rotary evaporator until all alcohol was evaporated and only the aqueous extract remained. The extracts were produced at 5\%, 10\%, and $15 \%$ concentration and incorporated into a pharmacological ointment and balm.

The ointment formulation comprised different percentages of the extract added at 40 and $60 \%$ respec- tively of polyethylene glycol 400 and polyethylene glycol 4000. In the balm formulation, the extract was added to a 50\% mixture of grape seed oil and almond oil.

\section{Phytochemical evaluation}

The crude hydroalcoholic extract was subjected to a sequence of reactions for the characterization and isolation of the constituent substances, such as naphthoquinone (acid/base reaction), characterization of flavonoids (reaction of cyanidine and sulfuric acid, A-I and A-II), tannins (reaction with iron salts, precipitation of proteins, B-I and B-II), coumarins (observation under ultraviolet light), triterpenes and steroids (LiebermanBurchard reaction), identification of cardiotonic heterosides (Baljet and Keddle, C-I and C-II), characterization of saponins (Lieberman-Burchard reaction and foam index), and the identification of the presence of alkaloids (Mayer, Hager, and Gragendorff method), in accordance with the methodology described by Simões et al. [24].

\section{Experimental model}

The experiment used forty 45-day-old male Wistar rats (Rattus norvegicus) with a mean weight of 180-200 g. All animals were kept in a controlled environment (temperature, $22^{\circ} \mathrm{C}-24^{\circ} \mathrm{C} ; 12 \mathrm{~h} / 12 \mathrm{~h}$ light-dark cycle) with access to rations and water $\mathrm{ad}$ libitum. The first 10 days were used to adapt the rats to the experimental phase. All protocols used in the research followed the resolutions of the Federal Council of Veterinary Medicine (CFMV), the Brazilian College of Animal Experimentation (COBEA), and were approved by the Ethics Committee of Animal Experimentation of Federal University of Viçosa (CEUA/UFV) under the approval number 113/2013.

For wound creation, the animals were sedated with acepromazine $1 \%(1 \mathrm{mg} . \mathrm{kg}-1 \mathrm{IM})^{2}$ and hair was trimmed in the dorsal region. The surgical region was washed aseptically with chlorhexidine alcoholic solution $(0.5 \%)^{3}$. In the incision region, was administered $0.1 \mathrm{~mL}$ lidocaine $1 \%$ (mg.kg-1) ${ }^{4}$ without a vasoconstrictor. With a circular scalpel of $6 \mathrm{~mm}$, two incisions were performed and the skin was removed. A distance of $2 \mathrm{~cm}$ was left between the incisions, following an adapted methodology of Carvalho [7].

The animals were divided into eight groups of five animals and administered different treatments based on combinations of vehicle (balm or ointment) and extract concentration $(0 \%, 5 \%, 10 \%$, or $15 \%)$, as shown in Table 1. 
Table 1. Distribution of treatments based on Sonchus oleraceus.

\begin{tabular}{cc}
\hline Treatment & Extract \\
\hline Ointment & $5 \%$ \\
Ointment & $10 \%$ \\
Ointment & $15 \%$ \\
Ointment & without active principle \\
Balm & $5 \%$ \\
Balm & $10 \%$ \\
Balm & $15 \%$ \\
Balm & without active principle \\
\hline
\end{tabular}

The wound evaluation was performed daily to assess clinical alterations, including signs of inflammation, erythematous halo, time of healing, and epithelization. The wounds were kept open and only the test products were used for 14 days.

Wound cranial-caudal length was measured with a digital pachymeter. The variable of "healing time" was determined when all the wound area was replaced by healing tissue (healing by second intention) and the time of epithelization was measured as the time when the tissue showed regeneration, in accordance with the methodology of Carvalho [7].

After 15 days, a biopsy was performed and the obtained samples were subjected to histopathological analysis and quantification of type I and III collagen fibers. The tissue biopsy fragments were stained with hematoxylin and eosin and observed by using a light microscope to assess the presence or absence and intensity of granulation tissue, hemorrhage, and inflammatory infiltration.

\section{Histochemical reaction for collagen}

Picrosirius staining of the histological sections was used for the analysis of type I and type III collagen fibers, as described by Junqueira et al. [13]. The stained sections were observed by using a polarized light microscope to differentiation the collagen types by color and birefringence intensity. The slides were photographed with a digital camera (5.0 megapixels) at 200x zoom. Three regions of each slide were photographed for each group. The photomicrographs were used for the calculation of collagen percentage by ImageJ software, using the Threshold Colour plugin, which obtained the percentage of collagen through automated particle analysis of the different colors in a selected area. All values were standardized for each type of collagen fiber. For type I collagen fiber, 0-40 red was used and 45-120 green was used for type II collagen, with saturation of 0-255 and 5-255 brightness for both.
Statistical analysis

The differences in all treatments were examined by using two-way ANOVA, with the presentation (balm or ointment) and the extract concentration ( $0 \%$, $5 \%, 10 \%$, and $15 \%$ ) considered as independent variables. To compare the means between groups, Tukey's test was applied. All statistical tests were computed by SigmaPlot 11.0 at the $5 \%$ significance level.

\section{RESULTS}

The phytochemical analysis demonstrated the presence of all tested compounds in the hydroalcoholic extract at $15 \%$ concentration.

The macroscopic evaluation of the wounds did not reveal erythematous halo, edema, or any sign of infection in any group. The healing time was not significantly different between the groups treated with the ointments with 5\% and 10\% extract (Figure 1). However, compared with the control group, these concentrations showed functional wound recovery. However, the ointment containing $15 \%$ concentration was more effective than the other concentrations or the control group, with wound retraction complete in a mean time of 10 days.

The balm with $5 \%$ extract showed promise compared to with the control group, but the difference was not statistically significant (Figure 2); in absolute terms, the balm with 5\% extract demonstrated $97.6 \%$ efficacy compared with the control (98.8\% efficacy). Thus, this product was not significantly effective, but did possessed pharmacological action.

Presence of granulation tissue, collagen fiber proliferation, and discreet mononuclear infiltration was observed in all histological samples. The presence of pilose follicles and sebaceous glandules was observed in the central area of tissue regeneration. This observation was most evident in the samples from the groups treated with $10 \%$ and $15 \%$ ointment; in these groups, the collagen fibers were more organized.

The mean values of the type I and III collagens fibers in the tissue samples collected after the different treatments are shown in Table 2. The most prevalent type of collagen fiber after both treatments was type I.

Treatment with balm containing 5\% extract, compared with the ointment, was statistically more effective (2.21\% increase in type I collagen fibers, < $0.05 \%)$. However, the rate of synthesis of type I collagen was greater than that of type III collagen. 


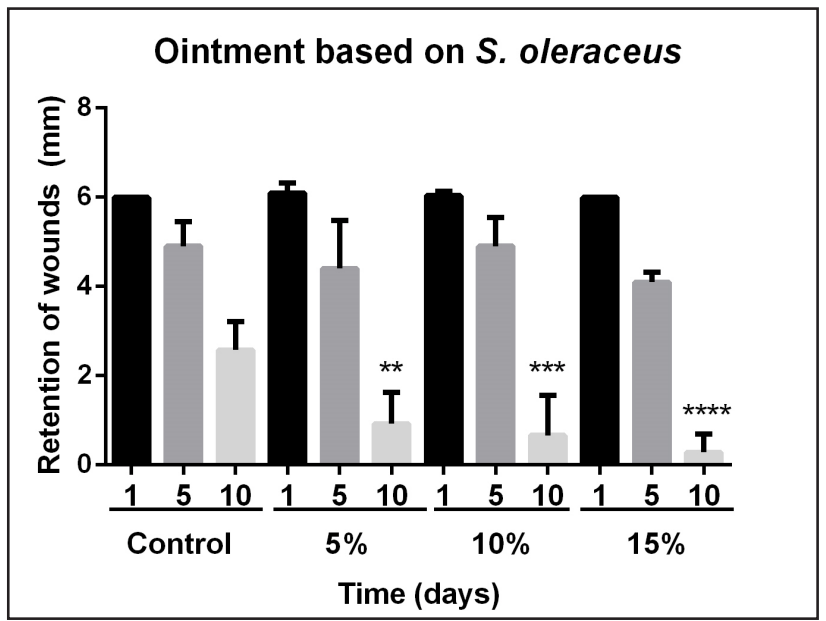

Figure 1. Retention of wounds (in millimeters) after application of ointment based on Sonchus oleraceus compared to control in a parameter of variance of $* *(<0,05) ; * * *(<0,01) ; * * * *(<0,01)$.

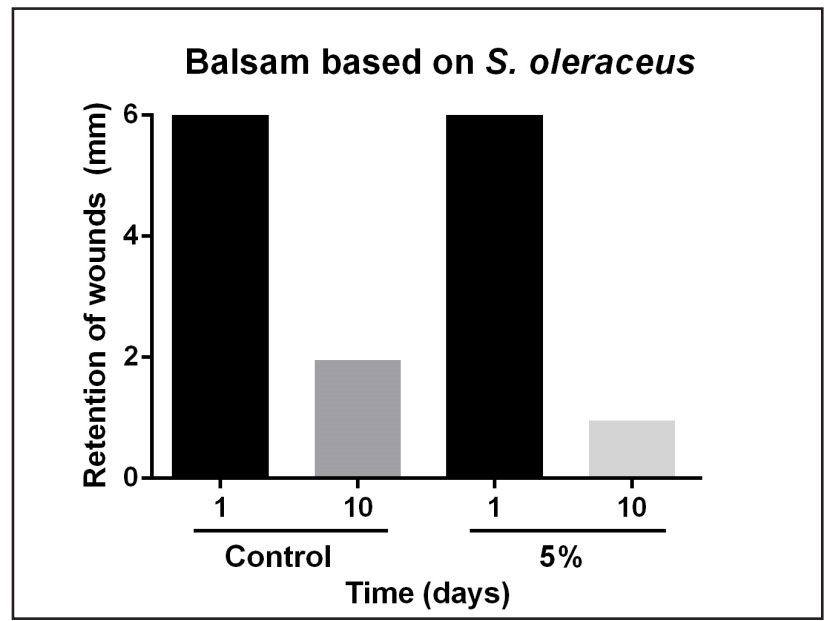

Figure 2. Retention of wounds (in millimeters) after application of $5 \%$ Sonchus oleraceus based balsam compared to control.

Table 2. The effects of Sonchus oleraceus (balm and ointment) on values of collagen fibers type I and III in the area of the wound. The contraction in rats was evaluated at the end of 15 days of treatment.

\begin{tabular}{cccc}
\hline & Extract & Collagen Type I (\%) & Collagen Type III (\%) \\
\hline & $0 \%$ & $10.106 \pm 5.051$ & $1.470 \pm 0.430$ \\
Balsam* & $5 \%$ & $29.591 \pm 4.124$ & $1.532 \pm 0.351$ \\
& $10 \%$ & $16.087 \pm 4.124$ & $1.649 \pm 0.351$ \\
& $15 \%$ & $22.603 \pm 4.374$ & $1.294 \pm 0.372$ \\
\hline \multirow{3}{*}{ Ointment* } & $0 \%$ & $17.218 \pm 5.051$ & $0.615 \pm 0.430$ \\
& $5 \%$ & $13.748 \pm 4.124$ & $0.511 \pm 0.351$ \\
& $10 \%$ & $9.491 \pm 4.124$ & $0.515 \pm 0.351$ \\
& $15 \%$ & $9.542 \pm 4.124$ & $1.083 \pm 0.351$ \\
\hline
\end{tabular}

*All groups presented statistical difference $(P<0.05)$ only for the presentation, with the predominant higher concentrations of collagens type I and III being found in the groups that received the extract in the formulation of the salve - ANOVA and Tukey, $\alpha=5 \%$.

\section{DISCUSSION}

Reduction in free radical activity in Sonchus oleraceus may be correlated to the presence of flavonoids. Other studies have proven that flavonoids, present in most parts of plants, exert reliable healing activity through the stimulation of fibroblast growth and collagen production [20]. Tannins are watersoluble vegetable metabolites that are abundant in nature and have the capacity to precipitate in contact with proteins [27]. Studies have demonstrated their intense antioxidant activity, antimicrobial effects, and anti-inflammatory characteristics $[15,25,26]$. The coumarins are a large group of 1,2-benzopyrone derivatives abundant in nature. Their pharmacological activity is of great interest, such as antioxidant, anti-inflammatory, and vasodilatory effects that can be used for the treatment or prevention of cardiovascular diseases [2,30].
Saponins are derived from the secondary metabolism of the plants and are directly connected to the defense systems such as the antimicrobial, antifungal, and photo-protective effects [4]. Alkaloids are present in plants and also exert antimicrobial and antioxidant functions [16]. Anthracenes and heterosides are prevalent in some plants and have many pharmacological activities, including laxative, antifungal, and antibacterial effects [29].

This indicated that the inflammatory phase occurred for a short time and was low in intensity. Jones [11] emphasized that the inflammatory phase is a dynamic process and is beneficial to lesions, directly inducing healing.

The increased effectiveness of the ointment containing extract of $S$. oleraceus may be correlated with the proportionately better skin penetration capac- 
ity of this pharmacological formula than the balm. Lima et al. [14] reported that high concentrations of flavonoids (anthocyanins and tannins) function in similar way to inflammatory mediators, causing the release of inflammatory cytokines and tumor necrosis factor, as observed in this study. The in vitro studies of Ross and Kasun [21] demonstrated the antioxidant power and free radical capture ability of phenolic compounds; in particular, flavonoids were highlighted. These compounds are not equally absorbed by the organism; after ingestion, the least absorbed are proanthocyanidins, anthocyanins, and catechins. The most readily absorbed compounds are flavanones, flavanols, and glucosides [8].

Flavonoids are important owing to their capacity for binding free radicals in an organism and function as an antioxidant factor [19]. In the inflammatory process, many cytokines, chemokines, adhesion molecules, and inflammatory enzymes, such as cyclooxygenases, can be active [20]; their anti-inflammatory effects may interfere in the final metabolism of the arachidonic acid. Phenols are also potent inhibitors of the nitric oxide synthase type 2 and lipoxygenase, which contribution to greater anti-inflammatory properties and even antinociceptive activity [18].

In this study, mononuclear inflammatory infiltration was observed, which confirmed the report of Beanes et al. [1] that this occurred because sample collection occurred during the late healing phase. The polymorphonuclear inflammatory infiltration takes a maximum of 3-4 days) [9].

Flavonoids can stimulate the production of some collagens, but inhibit others, which can be interesting in cases such as chronic wounds [28]. They also affect metalloproteinases, inhibiting their action and increasing collagen synthesis. However, the actions of flavonoids as an accelerator of the healing process should be considered, as well as their propensity to control exaggerated scars and skin aging. The authors affirm that flavonoids are capable of direct binding to the collagen fibers and of increasing their resistance to the action of collagenase. This means that the tested treatment, which is rich in flavonoid molecules, could significantly increase the collagen in the healing process.

Generally, tissue resilience is directly correlated with the amount of collagen of the dermis. Collagen fibers are characterized by interlacing fibers of $90 \%$ type I collagen and $10 \%$ type III collagen. This information allows the quantification of the density of the fibers in all phases of the healing process, which allows the analysis of the effects of treatments [23].

In this study, samples were collected 15 days after the wounds were completely healed (approximately 10 days). Greater quantities of type I collagen were found than type III collagen after both treatments, with the greatest concentration after treatment with balm containing $5 \%$ extract. It was reported by Shultz et al. [22] that for a wound in physiological conditions the expression of type I collagen at approximately 1 week after the wound was created would be approximately $80 \%$ quantity in the extracellular matrix. Type III collagen fiber was present in small amounts; however, this type is the first to be produced and is called immature collagen owing to its unorganized fibers. Type I has more organized fibers and replaces the type III collagen at the end of the healing process [3]; it constitutes approximately $8 \%-11 \%$ of normal skin.

\section{CONCLUSION}

The formulations with $80 \%$ hydroalcoholic extract of Sonchus oleraceus exhibited therapeutic action in the treatment of experimental wounds. The treatment with the ointment with an extract concentration of $15 \%$ resulted in greater tissue retraction than the other treatments. In all groups, type I collagen fibers were predominant, which was in accordance with the tissue healing process. Furthermore, wounds healed with both formulations, balm and ointment.

\section{MANUFACTURERS}

${ }^{1}$ Unique Indústria com Produtos Eletrônicos Ltda. Indaiatuba, SP, Brazil.

${ }^{2}$ Vetnil Indústria e Comércio de Produtos Veterinários Ltda. Louveira, SP, Brazil.

${ }^{3}$ Indústria Farmaceutica Rioquimica Ltda. São José do Rio Preto, SP, Brazil.

${ }^{4}$ Cristália Produtos Químicos e Farmacêuticos. São Paulo, SP, Brazil.

Funding. The authors thank CAPES, FAPEMIG and CNPq for the scholarship granted and financial support.

Ethical approval. All procedures were approved by the Ethics Committee in Animal Experimentation at the Universidade Federal de Viçosa (UFV)-CEUA (protocol n.113/2013).

Declaration of interest. The authors report no conflicts of interest. The authors alone are responsible for the content of the paper. 


\section{REFERENCES}

1 Beanes S.R., Dang C., Soo C. \& Ting K. 2003. Skin repair and scar formation: the central role of TGF-[beta]. Expert Reviews in Molecular Medicine. 5(1): 1-22.

2 Borges F., Roleira F., Milhazes N., Santana L. \& Uriarte E. 2005. Simple coumarins and analogues in medicinal chemistry: occurrence, synthesis and biological activity. Current Medicinal Chemistry.12: 887-916.

3 Borges L.F., Gutierrez P.S., Marana H.R.C. \& Taboga S.R. 2007. Picrosirius-polarization staining method as an efficient histopathological tool for collagenolysis detection in vesical prolapse lesions. International Research and Review Journal for Microscopy. 38(6): 580-583.

4 Castejon F.V. 2011. Tanino e Saponina. 29f. Seminário de Pós-graduação (Mestrado em Produção Animal) - Escola de Veterinária e Zootecnia, Universidade Federal de Goiás, Goiânia.

5 Carvalho A.C.B., Nunes D.S.G., Baratelli T.G, Shuqair N.S.M.S.A.Q. \& Netto E.M. 2007. Aspectos da legislação no controle dos medicamentos fitoterápicos. $T$ \& $C$ Amazônia. Ano V(11): 1-7.

6 Carvalho C.D., Moreira F.R.O., Bezerra K.S., Guimarães J.V.C.N., Cardoso J.C., Lima A.S., Jeraldo V.L.S. \& Melo C.M. 2011. Infecção parasitária e perfil sanitário de plantel caprino em área urbana de Sergipe. Scientia Plena. 7(3): $1-9$.

7 Carvalho G.D. 2013. Efeito da ingestão de água-de-coco e água magnetizada na reparação de feridas experimentais em coelho. 91f. Tese (Doutorado em Medicina Veterinária) - Departamento de Veterinária, Universidade Federal de Viçosa, Viçosa.

8 Clifford M. \& Brown J.E. 2006. Dietary Flavonoids and health - broadening the perspective. In: Andersen R.M. \& Markham K.R. (Eds). Flavonoids: Chemistry, Biochemistry and Applications. New York: Taylor and Francis Group, CRC Press, pp.319-370.

9 Junior O.L.C. 2007. A intensidade do infiltrado inflamatório agudo após irradiação laser de baixa potência (InGaAlP - 685 nm). 81f. Tese (Doutorado em Cirurgia e traumatologia Bucomaxilofacial) - Faculdade de Odontologia, Universidade Católica do Rio Grande do Sul.

10 Fraga M.I. \& Tasende M.G. 2003. Mechanisms of resistanceto simazine in Sonchus oleraceus. Weed Ressearch. 43(5): 333-340.

11 Jones T.C., Hunt R.D. \& King N.W. 2000. Patologia Veterinária. 6.ed. São Paulo: Manole, 1415p.

12 Junior V.F.V. \& Pinto A.C. 2005. Plantas medicinais: Cura segura? Química Nova. 28(3): 519-528.

13 Junqueira L.C.U., Bignolas G. \& Brentani B.B. 1979. Picrosirus staing plus polarization microscopy, a specific method for collagen detection in tissue sections. Histochemical Jornal. 11: 447-445.

14 Lima J.M., Silva C.A., Rosa M.B., Santos J.B., Oliveira T.G. \& Silva M.B. 2009. Prospecção fitoquímica de Sonchus oleraceus e sua toxicidade sobre o microcrustáceo Artemia salina. Planta Daninha. 27(1): 7-11.

15 Lim Y.Y. \& Murtijaya J. 2007. Antioxidant properties of Phyllanthus amarus extracts as affected by different drying methods. LWT - Food Science and Technology. 40(9): 1664-1669.

16 Marinho S.R.M. 2001. Função dos alcaloides indólicos monoterpenóides de Catharathus roseus (L.) G. Don. 68f. Porto, Portugal. Tese (Mestrado em Biologia do Desenvolvimento e Reprodução Vegetal) - Faculdade de Ciências, Universidade do Porto, Porto.

17 Novato D.A. \& Carvalho D.V. 2000. Tratamento de feridas: uma contribuição ao ensino de enfermagem. Revista Mineira de Enfermagem. 4: 47-51.

18 Nonato I.A., Oliveira T.T., Oliveira L.E.D., Silva R.S.R. \& Zatti R.A. 2010. Avaliação da atividade antinociceptiva de Camellia sinensis em ratos. In: Anais do XVIII Seminário de Iniciação Científica da UFOP (Ouro Preto, Brasil). 1 CD ROM.

19 Oliveira A.B., Barbosa G.S., Verdam M.C., Ohana D.T., Mendonça M.S. \& Meira R.M.S.A. 2014. Efeito analgésico e anti-inflamatório do extrato aquoso das folhas de trevo-roxo (Scutellaria agrestis A.St.-Hil. ex Benth. - Lamiaceae) em roedores. Revista Brasileira de Plantas Medicinais.16(2): 174-181.

20 Ribeiro A.F.C. 2012. Avaliação das atividades anti-inflamatórias, antiangiogênica e antitumoral de extratos da Arrabidaea chica (humb. \& Ponpl) B. Verlot. 92f. Tese (Doutorado em Ciência Animal) - Escola de Veterinária, Universidade Federal de Minas Gerais, Belo Horizonte.

21 Ross J.A. \& Kasum C.M. 2002. Dietary Flavonoids: Bioavailability, metabolic effects, and safety. Annual Review of Nutrition. 22: 19-34. 
22 Schultz G.S., Ladwing G. \& Wysocki A. 2005. Extracellular matrix: review of its roles in acute and chronic wounds. Disponível em: <http://www.worldwidewounds.com/2005/august/Schultz/Extrace-Matric-Acute-Chronic-Wounds. html $>$ [Accessed online in April 2018].

23 Silva W.W., Watanabe W.T., Cruz A.N.N., Bonvent J.J. \& Bissaco M.A.S. 2008. Quantificação e classificação automática de fibras colágenas tipos I e III. In: 21. ${ }^{\circ}$ Congresso Brasileiro de Engenharia Biomédica, Salvador. In: Anais do 21. ${ }^{\circ}$ Congresso Brasileiro de Engenharia Biomédica (Salvador, Brasil). pp.1535-1538.

24 Simões C.M.O., SchenkeL E.P., Gosmann G., Mello J.C.P., Mentz L.A. \& Petrovick P.R. 2000. Farmacognosia: da planta ao medicamento. 2.ed. Porto Alegre: Editora UFRGS, 1104p.

25 Sisti M., De Santi M., Fraternale D., Ninfali P., Scoccianti V. \& Brandi G. 2008. Antifungal activity of Rubus ulmifolius Schott standardized in vitro culture. LWT - Food Science and Technology. 41: 946-950.

26 Santos-Buelga C. \& Scalbert A. 2000. Proanthocyanidins and tannin-like compounds - nature, occurrence, dietary intake, and effects on nutrition and health. Journal of the Science of Food and Agriculture. 80: 1094-1117.

27 Monteiro J.M., Albuquerque U.P., Araujo E.L. \& Amorim E.L.C. 2005. Taninos: uma abordagem da química à ecologia. Química Nova. 28(5): 892ᄀ-896.

28 Stipcevic T., Piljac J. \& Berghe D.V. 2006. Effect of different flavonoids on collagen synthesis in human fibroblasts. Plant Foods for Human Nutrition. 61(1): 29-34.

29 Vendruscolo G.S., Rates S.M.K. \& Mentz L.A. 2005. Dados químicos e farmacológicos sobre as plantas utilizadas como medicinais pela comunidade do bairro Ponta Grossa, Porto Alegre, Rio Grande do Sul. Revista Brasileira de Farmacognosia. 15(4): 361-372.

30 Wu C.R., Huang M.Y., Lin Y.T., Ju H.Y. \& Ching H. 2007. Antioxidant properties of Cortex Fraxini and its simple coumarins. Food Chemistry. 104(4): 1464-1471. 